\title{
The Southern Highlands: A hasty transition from unknown to riches and chaos
}

\author{
Joe R. Kanekane
}

The late Mathew Kohai, a health adviser with the Department of Southern Highlands, still could not accept the recent developments in Mendi. Having lived there all his life, the Manus Islander was baffled that the once peaceful province is now a place of lawlessness. He sought answers, attempting to identify a particular cause, but could not find one. He recalled the days when systems were functional and public servants like himself were keen to work in the province. He was adamant that things would improve and had no intention of being transferred elsewhere.

The rest of the province is still banking on the hope that the province will return to normalcy. In the meantime, Mendi is still facing petty crime. Tari is constantly being tormented by armed thugs. Despite police presence, lawlessness continues on the peripheries, though in Ialibu, Kagua, Erave, and Pangia the law and order challenges are less. Public servants are fearful for their lives, and people have migrated to Port Moresby and elsewhere in the country.

The Southern Highlands Province has moved from an unknown province to an important source of revenue for the country. In the early 1990s successive governments placed emphasis on the discovery of oil and gas. Along with this came the opening up of new roads to wealth and influence, as well as social disharmony. The eastern end of the province ${ }^{l}$ has better road access to neighbouring Western Highlands Province, has enjoyed better health and government services, and has greater business opportunities. Lawlessness, anarchy and a general deterioration of government services have occurred more in the central and western ends of the province, which include Mendi and Nipa, where there have been roadblocks and tribal feuds, and Tari, which has been characterised by vandalism and lack of respect for law and order. The province's wealth is also concentrated in the central and western end of the province, which are blessed with natural resources and enjoy a lion's share of the proceeds from them through royalties and tax credit scheme funded infrastructural projects.

This paper will provide an overview of the province, seek to establish the causes of the present unrest, and examine what needs to be done to resolve the problems. However, it is not easy to find quick solutions. 


\section{History and geography}

It is believed that the Southern Highlands was settled nearly 20,000 years ago, based upon the dating of grinding tools found in Mendi. It was not until the mid-1930s, however, that exploratory patrols visited the Southern Highlands and opened it to the world.

Clarke (1982:15) notes that the first school in the province was established at Lake Kubutu in 1953, some eighteen years after first patrols entered the area. Schools were subsequently established at Mendi, Tari and Ialibu, and thence the more remote parts of the province. It was not until 1967 that the first secondary school in the province was established.

As the Southern Highlands was a slow starter, prominent Southern Highlanders travelled elsewhere for their education. Former politicians Sir Wiwa Korowi (Southern Highlands provincial member 1977-1982 and 1987-1991) and Peter Peipul (MP for Imbonggu 1997-2000) received their education at Awaba High School in the Western Province. Three-term Ialibu-Pangia MP, Roy Yaki (1987-2002) went to the Asaroka Lutheran High School. Other prominent Southern Highlanders were educated in the Western Highlands.

Little by little, development came to the province under the colonial administration. The Australian Army established an engineers' base in Mendi, and was involved in much of the province's civil and infrastructure development until their departure in 1996. According to Terry Boyce, who was a commanding officer of the unit and provincial works manager, the army was often asked to mediate disputes (quoted in Marjen 1981). The army engineers did an excellent job; at one stage, Southern Highlands was said to have the best Works department in the entire country.

\section{Early leadership}

Respect and esteem was accorded to traditional leaders, who established their reputations by giving pigs or other valuables in exchanges with other tribes (Wiessner and Tumu 1998:253). Crocombe (1983: Chapter 11) expounds on the concept of the Melanesian leader, arguing that political power was achieved through skills in production, organisational politics and war (also see Chao 1984). Melanesian bigmen plan productive activities, mobilise the resources of the group, and create wider groupings, at least temporarily, for inter-group cooperation through ceremonial events.

When the colonial administration introduced the positions of luluai and tultul, $^{2}$ the traditional leaders were a natural choice. They assisted the administration, especially in its efforts to understand custom and tradition. In the Southern Highlands, men like Turi Wari (MP for Ialibu-Pangia 1968-1977) and Matiabe Yuwi (MP for Tari-Pori 1968-1982) played this role. Prominent kiap Ron Neville made an early transition to politics, and became one of the first 
white men to serve as a member for the Southern Highlands. On the basis of his experience as a kiap and the respect he commanded, he represented the province from 1964-1977. Papua New Guinea's first Prime Minister, Sir Michael Somare, in his book Sana, records that Neville was a critic of Pangu's stand on colonial rule and had a memorable encounter with one of Pangu's stalwarts, the late Sir Albert Moari Kiki, during a session of the 1972 parliament (Somare 1975:63).

With Neville at the helm, and with a group of seasoned traditional leaders, including Paiele Elo (Koroba-Kopiago), Momei Pangial (Mendi) and Tegi Ebial (Nipa-Kutubu), the province was making steady progress towards its ultimate goal of electing more local leaders. Matiabe Yuwi was involved with the Constitutional Planning Committee, while the rest were involved in parliamentary committees. Yano Belo (Kagua-Erave) subsequently joined them, and was made a government minister soon after. Dame Rachel Cleland (1985) wrote of the potential of two Southern Highlands leaders, Andrew Wabiria and Momei Pangial. She was awed by their patience and willingness to understand the ways of the white man. Dinnen (1998:48) also gives credit to these leaders, noting that the 1972 election marked the beginning of the opening of the state to local participation.

It also marked the emergence of indigenous politicians as a significant new category of power broker, linking local power structures to economic institutions of the state. The election of former diplomat and high school teacher, Wiwa Korowi, who defeated Ron Neville in the provincial seat in the 1977 elections, was a major turnaround. Korowi, who had been a diplomat in Nigeria and Asia, was called on by Southern Highlanders to play a key role. He became Minister for Health, Public Utilities and Minerals and Energy under Michael Somare (1977-1980) and Sir Julius Chan (1980-1982). During this time he was successful in bringing the Pauanda and the Tari hydro power plants to the province. He upgraded health centres to hospitals and connected districts by telephone. The significance of the government's presence, and especially the role of elected leaders, was beginning to register with electors. Korowi also travelled extensively around the province, educating people about the changes taking place. This gave people a clearer picture of the government's objectives, and importantly let them get to know the province's regional member. Korowi lost the 1982 elections but was re-elected in 1987, defeating Francis Pusal. He remained in parliament for four years, resigning in 1991 to successfully contest for the office of governor general.

At the provincial level, outspoken Tari leader Andrew Andaija was elected interim premier of Southern Highlands. His interim cabinet contained seasoned provincial politicians. However, Andaija died in a plane crash in 1980; he was replaced by Tegi Ebial from Nipa. From 1980 to 1985 Ebial maintained the status quo, juxtaposing his cultural roots as a traditional leader with selective modern 
ideas. His experience in the House of Assembly helped him run the province. Ebial was defeated in 1985 by Yaungtine Koromba, who was premier until 1991. It was during Koromba's reign that the news of oil and gas discovery started shaking the province. Koromba played a key role during his time, signing on behalf of the provincial government its agreement to participate in the Kutubu Oil and Hides Gas projects.

Albert Mokai, an Arts graduate from the University of Papua New Guinea (UPNG), was elected premier in 1992, however his tenure was short-lived: the Southern Highlands provincial government was suspended and an administrator was appointed. When the suspension was lifted in 1994, Francis Awesa, a former provincial secretary, was elected premier. Awesa, a law graduate from UPNG, brought with him experience from the PNG Electricity Commission and the corporate circles where he was an executive. It was during Awesa's tenure that the royalty benefits from the projects were reviewed, paving the way for increased benefits. Awesa had been in office for only one year when the Chan-Haiveta government's provincial and local-level government reforms were passed. Awesa was relegated to deputy governor while regional MP Dick Mune (who had replaced Wiwa Korowi in a by-election in 1991) became governor. Disagreements between Mune and Awesa saw the latter sacked as deputy governor.

The premier's job was thus shared amongst leaders from all corners: Andaija from the west, Ebial from central, Mokai from the west, Koromba from central and Awesa from the east. On the national front, leaders like Glami Warena (MP for Imbonggu 1977-1987), Aruru Matiabe (1982-1992), Philemon Embel (Nipa-Kutubu 1987-2002), Anthony Temo (Imbonggu 1987-1997), and Michael Nali (Mendi 1992-2004) also played key roles as ministers.

The transition from traditional leaders to younger and more educated ones started in the mid 1980s. But despite the growing political maturity, Southern Highlands still lagged behind neighbouring Western Highlands and the other highlands provinces. Scores of labourers were hired by rich Western Highlands coffee and tea entrepreneurs to work on their plantations. Despite the discovery of oil, opportunities were restricted and Southern Highlanders found themselves increasingly marginalised and were prompted to seek opportunities elsewhere. Many of these labourers are still living on plantations, despite the collapse of coffee and tea estates, because they have access to better lives and services.

\section{Provincial and local level government reforms}

There is no doubt that the reforms vigorously advocated by the PPP-Pangu-led government in 1995 have been a failure. Acceptance of the new system came slowly, and the way the governors were able to position themselves was damaging. When Dick Mune ${ }^{3}$ realised his powers, he did not hesitate to use 
them. He sacked Francis Awesa as deputy governor and the member for Koroba-Kopiago, Herowa Agiwa, was elected by the assembly to replace him. Awesa maintains that he is still not aware of the reasons for his premature departure from politics (personal interview 2001).

Mune was a big-spending governor, who bought Land Cruisers for his council presidents and rewarded those who were aligned with him. There was talk that funds were starting to disappear. Under Mune, access to funds, materials and services that were previously restricted was freed up. Bogus invoices and other claims were forwarded to the provincial government. People of the Southern Highlands woke up to the fact that funds were available to those aligned with the ruling regime. Crowds of people started congregating around the Mune camp, and people from all parts of the province looked to him as the man with the money. He surpassed his predecessors in changing people's perceptions. Council presidents became powerful in their constituencies. Cash flowed into the peripheries, and people saw Mune was a true leader. He was, in many respects: he had several wives and concubines, he was a village leader and a very powerful orator, and, above all, he was a grass-roots-oriented person and people found it easy to deal with him. John Opengi, former lord mayor of Mendi town, once gave Mune the title of 'action man'; the people's money, he said, was now in their own hands. Robert Tawa, Ialibu Basin local level government president, echoed this sentiment, asserting that Mune did not care how much he gave, as long as it served a greater number of Southern Highlanders (personal interviews, 1997).

During the 1997 election campaign, Dick Mune held a rally at the Nipa station. Hundreds of supporters from around the province showed up to express their support. They gave cash and verbal pledges, and spoke of a new style of leadership that had dawned on the province. They urged voters to grant Dick Mune a second term. Prime minister, Sir Julius Chan, and Constitutional Development Commission chairman, Ben Micah, staunch PPP front-liners, praised Mune's leadership. Sir Julius in particular asked supporters to vote for Mune for a second term so that the PPP legacy could continue. He described Mune as a strong highlands leader, and said that after 1997 people like him would take the PPP reins. He also named Nipa (Mune's local area) as 'Number Two Namatanai', which delighted the crowd. On that occasion Mune slaughtered more then 500 pigs, which were distributed to those that attended. But despite his great popularity and his campaign strategies, Mune lost the 1997 election to the independent Huli candidate, Anderson Agiru.

\section{The Court of Disputed Returns}

When Mune lost the election, the dreams of his supporters were shattered. ${ }^{5}$ They did not know what to do, other than to rally behind Mune as he proceeded to contest his loss, filing a petition with the Court of Disputed Returns against 
Agiru's win. As a result of the dispute, Agiru - who was from the Tari district in the Hela area - refused to stay in Mendi; he claimed his life was in danger and chose to live in Moresby, governing the province from there.

As the court battle dragged on, tensions grew between the Hulis and the people of Nipa. The discontent of the Nipas began to show in small roadblocks, and the harassing of PMVs and commuters. When Mune lost his life in a car accident in 1999, people blamed Agiru. The argument was that Mune had won the election fairly, but because of Agiru's disputed win was forced to seek legal redress, which resulted in his death. Some went so far as to accuse Agiru of sorcery both in winning the election and in causing Mune's car to crash.

Faced with such accusations, Agiru chose to remain permanently in Port Moresby, although he assisted in Mune's funeral arrangements. He dealt with the provincial administration but was never there to see the people. If he travelled to the province, he was there briefly and then returned to Port Moresby. His administration, too, spent long periods in Port Moresby seeking directives from Agiru. Deputy Governor Wambi Nondi remained in the province, apart from sojourns to Port Moresby, but was not as influential as Agiru. Agiru's absence provoked a lot of people, and the law and order situation in Nipa started getting out of hand, with frequent roadblocks.

After the Skate government lost a vote of no confidence in 2000 and Sir Mekere Morauta became prime minister, the provincial government's powers were withdrawn and the incoming PDM government appointed one of its experienced party men, Pila Niningi, as administrator. Niningi, who was from Ialibu, ran the province for a short while before being displaced.

The boom period initiated by Mune had come to an end; people looked to Agiru to continue the flow of money, but it did not happen. Agiru's absence from the province contributed to their frustration. Even in Agiru's district of Tari, violent crime started to increase. Mendi followed, and by 2001 Southern Highlands had major law and order problems. Some argued that had Agiru remained in the province, travelling and conversing with the people, the situation would have been different. However it is not clear that this would have been the case: a spontaneous development of violence took place in the province, exerting pressure on government services. In project areas such as Hides and Kutubu, landowner tensions were rising: power pylons were being brought down, and roadblocks were apparent in the Hides project area. Mendi became a fighting zone in 2001, with businesses shutting down, the school of nursing closed, public servants fleeing, and anarchy prevalent. A tribal feud between the Tunjup and Unjumap groups escalated; the death toll rose with the proliferation of high-powered weapons, and the hiring of mercenaries becoming increasingly common. Southern Highlands was in the news daily, with reports of violence and mayhem. Police and the Morauta government tried to do 
something, but Mendi's woes increased, and for some time the town was almost deserted. However, Agiru left a legacy: the six-storey Agiru Centre in the middle of Mendi town.

\section{The churches' role in peace mediation}

Bishop Stephen Reichert of the Mendi Diocese, and Bishop Clarence Kapali from the United Church said they both felt obliged to do something to discourage fighting and promote peace mediation in the Southern Highlands. In separate interviews they described their efforts to solve the tribal fight in Mendi. The subsequent truce in Mendi was a credit to the two of them, but also to Francis Awesa, the former premier. In a separate interview he said that something had to be done about the state of affairs in the province. Awesa was particularly concerned that, as a local leader from Mendi, he had an obligation to assist the peace process. Along with the two church leaders, he helped organise the first surrender ceremony, which was witnessed by hundreds of warring clansmen. The ceremony was hailed as a success, though Awesa admits spending his own money to get the process under way. He also enlisted the tribal leaders and acknowledged their courage and willingness to stop the fighting. However the initial impetus, and the fine work done by the two churchmen, assisted government agencies to sustain the peace efforts. Both Bishop Reichert and Kapali have been held up or threatened by raskols a number of times. However they have persisted and as a result Mendi is slowly getting back to normalcy.

Tari is also experiencing some problems, but it is hoped that the presence of police will improve the situation. Former Tari police station commander, Simon Nigi believes people are willing to assist the peace process. He says the challenge is for leaders to bring themselves down to the people's level so that they can understand how the challenges are being met. Police are working around the clock and Simon Nigi has travelled extensively and talked with people, hoping that, by understanding the people, he can devise practical means to deal with the challenges.

Prominent Southern Highlander and former diplomat Dominic Diya believes the absence of competent administrators in the province has had negative results (personal interview 2001). He is adamant that unless competent administrators are on the job, the province cannot prosper. Diya, who was once provincial administrator, argues the province can be managed with limited funds, if professionals are appointed to the top posts. However, people have become used to getting handouts. The Southern Highlands desk within the Finance Department is having a nightmare sorting invoices and claims amounting to hundreds of thousands of kina.

As Whiteman (1984:38) argues: 'culture changes when the ideas that people hold in common change. Change begins with individuals and their ideas and as 
these new ideas spread throughout society culture begins to change'. People have aligned themselves with the governor or politicians in order to gain something for themselves. During his tenure, Mune promoted this. It has made for a difficult transition.

\section{The future}

Utting et al (1995:168) suggests a broad framework within which law and order problems can be addressed: if people are to interact with their neighbours on equal terms and participate in the political process, access to public services is essential. We have seen the failings of Agiru's leadership style and that of the late Dick Mune, which have brought about the present state of affairs in the province. People use a variety of means to show their frustration with governments, but if they receive the services they need - health, education, roads and so on - such frustration can be overcome.

Many communities are now being asked to take on new responsibilities by organisations who wish to mobilise them for purposes that may or may not coincide with the communities' own perceptions of their needs. Superintendent Nigi, on the other hand, seeks practical solutions, talking with the people, at their level, throughout the Hela region. There is no doubt that the majority of Southern Highlanders want a peaceful province. We need to look at where they want the province to go. Educated Southern Highlanders, and successful sporting personalities, should be encouraged to rally together and appeal to their people for peaceful change.

Radio Southern Highlands should also be supported. The station manager, Andrew Meles, believes that Radio Southern Highlands can assist by promoting positive news. He says information is crucial, and it is important that leaders use radio to communicate with the masses. Southern Highlands who can, regularly tune in to Radio Southern Highlands, and the station receives requests and messages from across the province. Meles observes that the station was involved in the Mendi peace ceremony, communicating with the two warring tribes through public radio. Such initiatives can work well on the ground.

Once the people are on side, the next challenge is to educate and inform them. The situation in the eastern end of the province is progressing steadily. However the central and western parts of the province (Tari and Koroba districts) are badly affected by the social tensions. Banks and trade stores remain closed and government offices remain empty.

On a positive note, Southern Highlanders will rally together, as is evident in the Inter-City Rugby Competition when the Mendi Muruks are playing. We need to identify other measures to unite the province. Efforts by Peace Foundation Melanesia and Youth Ambassadors for Peace, largely driven by the 
churches, should be supported by government and donor agencies. Government should take heed of the various peace ceremonies and arms surrender ceremonies.

The challenges which the province faces are mostly a result of hasty transition, which has consumed people unable to deal with its impact. But people are tired of violence and lawlessness and want to get on with their lives. They know what violence can do to them, and many are committed to a better and safer society. They need initiatives that are meaningful and sustainable. There is still hope that these can be found and that the situation in the province turned around.

\section{References}

Chao, M. J. P. 1984 'Leadership', in D. Whiteman (ed.), An Introduction to Melanesian Cultures: A Handbook for Church Workers. Point No.5. Goroka: Melanesian Institute, pp.127-148.

Clarke, R. 1982 Education in the Southern Highlands. Five year Plan 1982-1986.

Cleland, R. 1985 Pathways to Independence: Story of Official and Family Life in Papua New Guinea from 1951 to 1975. Cottesloe, WA: R. Cleland.

Crocombe, R. 1983 The South Pacific: An Introduction. Auckland: Longman Paul.

Dinnen, S. 1998 'In weakness and strength — state, societies and order in Papua New Guinea', in P. Dauvergne (ed.), Weak and Strong States in AsiaPacific Societies. Canberra, A.C.T : Allen \& Unwin in association with the Dept. of International Relations, Research School of Pacific and Asian Studies, The Australian National University, pp.38-59.

Marjen, B. 1981 'Aust army is what counts in Southern Highlands', The Times of Papua New Guinea, 11-17 December, p.13.

Mantovani, E. 1987 'Traditional values and ethics', in Susan Stratigos and Philip Hughes (eds), The Ethics of Development. The Pacific in the 21st Century. Papers from the 17th Waigani Seminar, volume 1. Port Moresby: University of Papua New Guinea, pp.188-201.

Somare, M. 1975 Sana: An Autobiography of Michael Somare. Port Moresby: Niugini Press.

Utting, P., et al. 1995 States of Disarray: The Social Effects of Globalisation. Geneva: United Nations Research Institute for Social Development.

Whiteman, D. (ed.) 1984 An Introduction to Melanesian Cultures: A Handbook for Church Workers. Point No. 5. Goroka: Melanesian Institute.

Wiessner, P. and Tumu, A. 1998 Historical Vines: Enga Networks of Exchange, Ritual and Warfare in Papua New Guinea. Washington DC: Smithsonian Institution Press. 


\section{ENDNOTES}

1 The 'eastern end' refers to the districts of Ialibu, Pangia, Kagua and Erave. Mendi and Nipa are generally accepted as the centre. Magarima, Tari, Komo, Lake Kopiago and Koroba constitute the 'western end'.

2 The titles of luluai and tutul were generally given to outstanding men in communities. Their job was to represent the colonial administration by upholding law and order and promoting communal harmony.

3 Dick Mune was educated up to year eight. He joined the Royal Papua New Guinea Constabulary and served as a police commander in Wapanemanda, Mendi and Ialibu. He contested the 1982 and 1987 general elections, and won the 1991 by-election when incumbent Wiwa Korowi resigned to become governor general. He was a backbencher in the Wingti-Chan government from 1992-94, but following a government change was given the Housing ministry. He resigned to become governor in 1995.

4 Namatanai, in New Ireland Province, was Sir Julius Chan's own electorate.

5 Mantovani (1987) describes such loyalty as a transference of values from supporters to their leaders. These values are embedded in the subconscious and expressed through customs. People feel strongly, but often do not know why. 